The contested space that local knowledge occupies: understanding the veterinary knowledges and practices of livestock farmers in the Eastern Cape Province, South Africa

Book or Report Section

Updated Version

Proof

Ainslie, A. (2017) The contested space that local knowledge occupies: understanding the veterinary knowledges and practices of livestock farmers in the Eastern Cape Province, South Africa. In: Sillitoe, P. (ed.) Indigenous Knowledge: Enhancing its contribution to natural resources management. CABI, Wallingford, pp. 51-62. ISBN 9781780648118 Available at http://centaur.reading.ac.uk/75472/

It is advisable to refer to the publisher's version if you intend to cite from the work. See Guidance on citing. 
All outputs in CentAUR are protected by Intellectual Property Rights law, including copyright law. Copyright and IPR is retained by the creators or other copyright holders. Terms and conditions for use of this material are defined in the End User Agreement.

\section{www.reading.ac.uk/centaur}

\section{CentAUR}

Central Archive at the University of Reading

Reading's research outputs online 


\title{
5 The Contested Space that Local Knowledge Occupies: Understanding the Veterinary Knowledges and Practices of Livestock Farmers in the Eastern Cape Province, South Africa
}

\author{
Andrew Ainslie ${ }^{1}$
}

When concepts such as 'the knowledge economy' and 'intellectual property' roll so easily off the tongues of such diverse social actors as politicians, bureaucrats, scientists, the legal fraternity and the advocates and spokespersons for 'indigenous' rights around the world, it is clear that the production and 'management' of knowledge has moved centre stage. As innovations in information technology continue their rapid evolution, there are now arguably more instances of contestations over knowledge management, a situation which points to the ever greater strategic value of certain knowledges.

But a significant product of the 'knowledge economy' is the uncertainty that arises because of the surfeit of (often conflicting) information available via the worldwide web, on radio and television and in the print media (cf. Beck, 1999). Access to such information allows us all to fundamentally question scientific orthodoxies and accepted 'expert' knowledge systems and to weigh up evidence for credibility, salience and legitimacy (Cash et al., 2003). As a result, what is suddenly more important than ever is the need for criteria by which to evaluate, i.e. make value judgements about, information that comes to us 'packaged' as knowledge (Sillitoe, 2010).
The concern in this chapter is that ever increasing rates of technological innovation

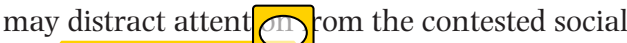
and politico-econol Jontexts in which knowledge is produced, reformulated and disseminated (Shepherd, 2010). It is precisely these contexts which shape or deliver the criteria for the evaluation of what might be called the certification of knowledge. The case stu $D$ esented here demonstrates that both the politi context and complex social relationships between bearers/users of different knowledges are important to consider in this regard. The chapter examines how livestock keepers come to hold different registers of basic and specialist local knowledge in areas of their agricultural practice. Attention is focused on the tensions that exist between local knowledge and scientific ideas whilst recognizing that the knowledge that herders have and use is a hybrid of these two idealized forms. It is suggested that such tensions persist in many, perhaps all, farming contexts worldwide.

The chapter examines the local knowledge system implicated in the production and husbanding of livestock, and specifically in relation to the management of tick-borne diseases of cattle. The focus falls on the largely rural Ngqushwa

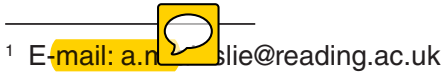


Municipality (formerly 'Peddie District'), which lies on the eastern seaboard of South Africa and forms part of the Eastern Cape Province (Ngqushwa IDP, 2002; Ainslie, 2005, 2013); see Fig. 5.1. This part of the country is recognized as having a virulent tick-borne disease challenge with respect to livestock. To shed light on these issues, the chapter explores some salient components of rural farmers' existing veterinary knowledge nd indeed their assumed 'ignorance', which is, after all, the flipside of knowledge.
To begin with, it is especially puzzling why, after nearly a century of a very regular, government-sanctioned and (in part at least) scientifically endorsed (see below) dipping programme for all cattle, most rural African farmers still fail to make an explicit causal connection between the heavy loads of ticks on their cattle and the prevalence of tick-borne diseases (TBDs) like redwater, heartwater and gallsickness. Rather, ticks are seen as a serious irritation in that they attack their cattle, sucking their blood and

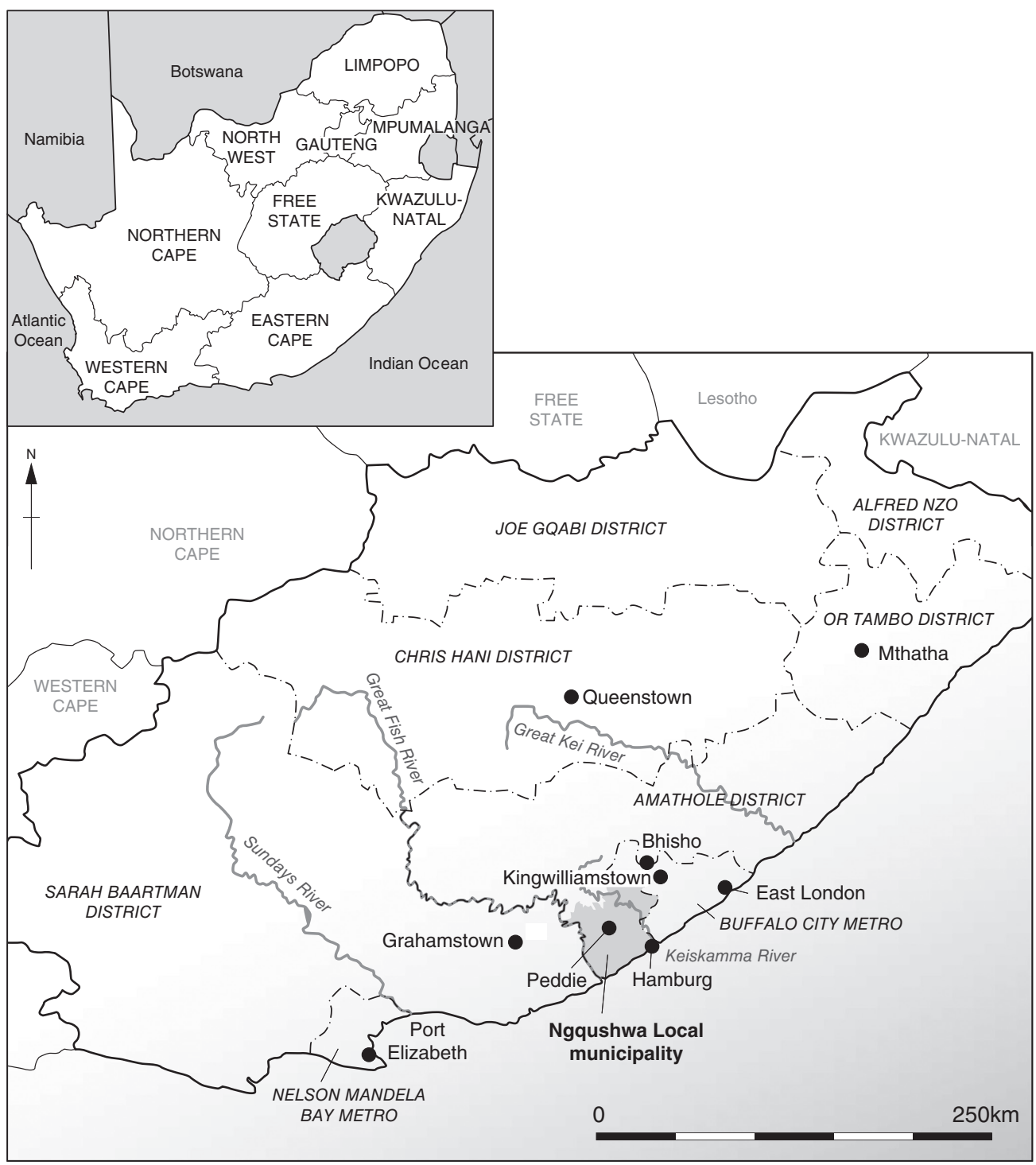

Fig. 5.1. Map of the Eastern Cape Province of South Africa. 
robbing them of their strength. Although this lack of association between ticks and TBDs seems highly unlikely after decade upon decade of an official dipping programme, it is telling that the cattle farmers interviewed did not see redwater or heartwater as a problem, with many saying they had not encountered it in their own herds. This is surprising, since this area is part of the coastline that is characterized by virulent heartwater and redwater which kills cattle in significant numbers every year.

This, it turns out, is not simply a translational issue that could be resolved through dialogue relating to causes and symptoms between practitioners using different or hybrid knowledge systems. At its heart lies a fundamental disconnect about what ticks can and cannot do to a bovine animal. In this chapter, the considerable uncertainty around knowledge relating to animal disease must be understood in relation to: (i) the political context/legacy of South Africa, which over the past century has not only shaped the (communal) livestock health management regimes and limited the agency of cattle farmers, but also, as a system of knowledge, been predicated on weak regimes of trust on the part of farmers in relation to authoritative knowledge pronouncements; (ii) substantive (though inadequately documented and shared) shifts in the scientific understanding of tick-borne livestock disease - see below (Tice et al., 1998; Brown and Gilfoyle, 2007); and (III) the dynamic, intrinsically social character erders' specific (natural and supernatural) challenges and thus practices for managing stock diseases - and specifically ticks and TBDs.

\section{What are Regarded as the Essential Characteristics of Local Knowledge?}

Anthropologists have long problematized research on local (or 'indigenous', 'customary', 'traditional', etc.) knowledge (Marchand, 2010, p. S3). More critical work has focus on the hybridity or 'admixtures' of knowledge and cultural practice (Agrawal, 1995, 2002). Indeed, in constructing his model for the analysis of knowledge, Barth (2002) avoided the increasingly sterile dichotomy of scientific versus indigenous knowledge. Attention is now regularly paid to the various ways in which both scientific knowledge and folk knowledge come to be integrated in people's existing epistemologies and knowledge pathways (Brown et al., 2013). Sillitoe (1998) made the important point that much of this mixing and learning is non-verbal: people 'transfer much knowledge between generations by tradition learnt and communicated through practical experience and are not familiar with trying to express everything they know in words... Knowledge is passed on by informed experience and practical demonstration; more often shown than articulated, it is as much skill as concept' (Sillitoe, 1998, p. 229).

What is clear is that if knowledge is to serve people in the ever changing circumstances of their daily lives, it must be constantly reconfigured, updated, refreshed, whether through tacit practice or more conscious, formal learning. But what is it about the provenance and method/media of transmission of new knowledge, improvisations and technologies that allow some types/modes to be assimilated into people's existing knowledge 'systems' and their daily repertoires while others are rejected? In his influential paper, Barth (2002) provided several avenues for fruitful enquiry and insightfully argued that knowledge consists of three aspects.

Firstly, it exists as a 'corpus of substantive assertions and ideas about aspects of the world that rests partly on valid inference, notably through believing what the people we trust tell us they know' (Barth, 2002, p. 3). He pointed out that in analysing knowledge systems, we tend to focus on 'generalisation, consistency, and a logical coherence' when in reality, knowledge is quite rarely so systematic (Barth, 2002, p. 7). Indeed, other research has shown that we all get by with a surprisingly large degree of what social psychologists and economists refer to as 'cognitive dissonance' (see for instance, Akerlof and Dickens, 1982).

Secondly, knowledge 'must be instantiated and communicated in one or several media as a series of partial representations in words, symbols, pointing gestures, actions' (Barth, 2002, p. 3).

Thirdly and crucially, knowledge is 'distributed, communicated, employed and transmitted within a series of instituted social relations ... [o]f trust and identification, and instituted authority 
positions of power and disempowerment' (Barth, 2002, p. 3).

Barth further observed that people within a single community may participate in different ways and modes in multiple social knowledges. In addition, he noted that 'branches' of knowledge are not evenly distributed across groups of people (cf. Sillitoe, 1998, p. 232). Warren (1998, p. 244, in section 'Comments to Sillitoe') expanded helpfully on this notion of multiple social knowledges, by distinguishing between three types of knowledge for any domain: 'basic core knowledge is possessed by virtually all members of a community and provides the basis for communication on a given topic; shared knowledge that expands on the core knowledge and allows persons occupying related occupational niches (like herders) to communicate using a more nuanced vocabulary and conceptual apparatus and specialised knowledg Win an occupational niche that most others in the community do not require' (italics added). This is a useful differentiation of knowledge types to which I shall return below in relation to the practices of cattle herders in rural South Africa.

For Barth, while the processes that underpin these distributions of knowledge are of considerable interest, it is the agency of 'the knowers the people who hold, learn, produce, and apply knowledge in their various activities and lives' that are central in his analysis (Barth, 2002, p. 3). Critically, it is in the social contexts in which people interpret and act in the world that the all-important criteria of validity for the knowledge (i.e. the knowledge about knowledge) that people hold are generated (cf. Sillitoe, 2010). In some social settings, they have latitude for improvisation and innovation; in others, they have virtually none.

Sillitoe (2010) usefully extended in several ways Barth's analysis of how knowledge is transmitted through time and beyond a specific social grouping. In particular, whereas Barth alludes to the issue of trust in the acts of validating inferential knowledge, it is this aspect that is central to Sillitoe's argument. He showed that the Wola people of Papua New Guinea, like other peoples (such as the indigenous Australians and Quechaspeakers in the Andes of Latin America), have an abiding concern - and one that is embedded in their complex language - for validating and assessing the trustworthiness of any communication. Given that they live in a stateless polity, the Wola have no recourse to an authority (such as that provided by state-endorsed education systems), which can 'standardise what is known and can adjudicate when persons disagree and settle who is right' (Sillitoe, 2010, p. 22; cf. Harris, 1997, pp. 113-114). Foreign as it may seem to our sensibilities, a social context and a lived reality in which there is no recognition of experts and their claims to superior knowledge is thus the context for a constant interrogation of people's knowledge statements. This forms an integral and meaningful part of Wola everyday speech. Is there a parallel in the context of the rural Eastern Cape?

\section{The Role of Ignorance - the Flipside of Local Knowledge}

In its crudest sense, 'ignorance' (Kirsch and Dilley, 2015) of formal, rational, cause-and-effect science on the part of the rural Xhosa-speaking cattle herders in the Eastern Cape, as elsewhere in rural South Africa, rests on the cruel legacy of colonialism and apartheid's racist, impoverished 'Bantu Education' system (Nasson and Samuel, 1990). Historically, few African people managed to secure more than a primary education. Those who did were exposed to the didacticism of the few 'Mission' schools that dotted the rural countryside. It is only in the past 30 years that a significant minority have had the opportunity to attend universities and other tertiary institutions, and even then the general state of rural primary and secondary schooling has remained abysmal: as recently as 2005 , the mean number of years of formal schooling for adults in Ngqushwa Municipality (in the central Eastern Cape Province) was a mere 6 years. Functional literacy stood at a low $55 \%$ across the board and a paltry $13 \%$ of rural residents had 12 years of secondary schooling or more.

So 'ignorance' (understood as being poorly uneducated in the formal sense) exists here, as it does in many of the impoverished areas of South Africa. The migration to cities and towns of those fortunate enough to complete post-secondary education, leaving the bucolic rural life behind, further reinforces the rural educational deficit.

An important consequence of this is that those who have progressed through the formal 
higher education system - for our purposes in the agricultural sciences - have consistently encountered a denigration of their cultural experiences and their local practical knowledge of agriculture in favour of a textbook-based 'scientific' model (in, for instance, plant and animal diseases and their control) of learning and knowing. They have been force-fed via textbooks and study materials an alienating emphasis on economic efficiency, using the individual profitoriented cattle farmer as the model for what a 'modern, commercial farmer' should resemble. This approach has undermined their confidence in their 'core' local knowledge and, with it, their agency and shared practical knowledge of bovine management and disease control in a village context. They have repeatedly been told that their prior local knowledge was a form of ignorance that lacked scientific certification and should be wholly abandoned.

In addition, their new learning has driven a wedge between the knowledge systems and practices of less educated older and younger men and the young men with tertiary qualifications in agricultural sciences. Many of these educated young men continue to keep cattle at their rural homes and a sizeable number of them are employed in technical and extension positions in the Department of Agriculture's Animal Production and Animal Health teams (Modisane, 2009; Beinart and Brown, 2013; Brown et al., 2013).

There is a third layer of 'ignorance' in the form of a significant de-skilling (Stone, 2007) over time, which rests on other parameters: the long years that most rural men spent working as migrants, often down the mines or in industry, in distant townships and cities, has had a telling impact on their lives and agency. Many of the older men have spent decades away from their home village, returning only in December or sporadically when their employment contracts expired or some family crisis required their presence in the rural village. Some had left small herds of cattle in the care of wives, young sons or elderly kinsmen, learning of the fortunes of their cattle through letters from home or verbal messages passed along by other migrants to the city or mining compound.

Many of them never lost their boyhood connection to and basic knowledge of rural environments that they acquired as herders of cattle. In particular, they have valuable local knowledge about where to drive their herds of cattle in times of drought or when the rangeland is freshly burnt and grazing is low (Bennett et al., 2010, 2013). They have also inherited, from their fathers and grandfathers, long-standing relationships with kinsmen in other parts of the district with whom they can exchange animals when the consecutive years of low rainfall threaten their animals. But in their years of absence from the village and in their retirement, their store of dynamic, adapting local knowledge, in this case specifically their ability to deal with bovine diseases, has tended to ossify over time.

A fourth perspective on the way ignorance 'works' as a key part of local knowledge that differs from a scientific causality relates to people's ways of inferential knowing and acting that specifically invoke the supernatural (Dilley, 2010; Ainslie, 2014). In this category, beliefs in both the positive supernatural power of ancestor intercession and, to a lesser extent, clan totems, and the negative supernatural power of witchcraft, albeit both strongly intermeshed with Christian beliefs in this area, inform and shape many Xhosa-speaking people's daily practice and understandings of causality. This is the case because cattle feature centrally in Xhosa ritual practice, including slaughtering for the ancestors, and as a symbol of the homestead. Arriving at explanations of both common livestock diseases and extraordinary events, for instance why a particular cow is struck by lightning, frequently involves invoking the supernatural. Moreover, the process of rationalizing between the possible causes to arrive at a solitary explanation for a particular event (such as the unexplained illness or death of a prized heifer) is seldom final or unequivocal, certainly not in relation to the observable causes. Rather, it remains open to a protracted social dialogue and a process of assessing the efficacy of the various ritual actions to counter the misfortune.

\section{Is Local Knowledge about Tick-Borne Diseases a 'Specialized' Knowledge?}

It is immediately clear that, in the villages of Ngqushwa Municipality, animal health knowledge is not a 'shared' knowledge that all or even most livestock owners possess in equal measure 
(Masika et al., 1997). While all these farmers both 'inject' (with biomedical veterinary products) and 'seza' (treat with 'traditional' Xhosa remedies using decoctions of indigenous plants) their animals as part of a disease preventive regime (Dold and Cocks, 2001; Moyo and Masika, 2009), they are often reluctant to share knowledge about specific medicines and remedies with each other. Dumisa mentioned his uncle Bilman who he said was a 'cruel' man. Bilman had good medicine: he knew how to cure cattle using amayeza yesixhosa (Xhosa medicine). Dumisa had tried to soften him up, by doing favours for him and hoping Bilman would help him out with his cattle. But Bilman did not like to share his knowledge with anyone. He treated his own cattle with a mixture that he made himself and his cows were always very fat and each cow produced a calf every year. But 'when you ask him - even as a close relative - to give you some of the same medicine, he either refuses or does so reluctantly and you are never sure if the stuff he gives you is the full-strength medicine or just a watered down version,' Dumisa told me. He went on to say that when he used this medicine on his herd, it did not have the same effect as it did on Bilman's own herd.

However, with his elderly female neighbour, Ngenelwa, Dumisa enjoyed more success: inside the entrance to Dumisa's cattle byre he kept a bottle of mayeza known as magonsana. It was made with the root of a plant that Ngenelwa knew where to find in the forest. He asked her for it and she went to find some and gave it to him. The problem he had was that one of his animals was stabbed by another animal in the kraal (cattle enclosure) after being pinned to the inside of the kraal. Dumisa noticed that when it urinated, the urine was red, i.e. was mixed with blood. He was worried that it was looking weak as well. He grated the magonsana root and then boiled it in water and decanted it into a $2 \mathrm{l}$ bottle. Dumisa had to administer it to the affected cow over 2 days in two $750 \mathrm{ml}$ doses and this would effectively remedy its problem. This mixture would clean out its blood and its system inside the body and in a few days it should not be urinating blood and should be sturdy again.

Matshoba (a community animal health worker) revealed that he knew certain amayeza yesixhosa remedies that his father had taught him, but these were his secret because if he gave them to others for their sick animals and the animal died, they would 'come back' to him with questions. He had shared some remedies with his wife's sister in a nearby village when her goats needed medicine and it worked fine. He had also helped some men in his own village, but he did not like doing it. Also, he felt that you should not mix 'a needle' (purchased medicine) with 'a bottle' (amayeza), but his explanation of his own practice contradicted this. He used Xhosa mayeza for the tick-borne disease known as 'redwater', but when a cow was already sick, a needle with Hitet was more effective, because it worked faster. Asked to explain this, he said that amayeza were better for prevention than for curing very sick animals. When someone stabbed his young ox at night, it was bleeding internally (isivubeko - an internal wound), which he deduced because it was excreting blood. He used a needle and injected it with Hi-tet and also made a Xhosa medicine called umhlavuthwa 'to clean it out inside'.

One of Xolani's animals had an intambo (a leather strop tied around its neck). He said it apt rid of the intsumpa (warts) on the head, bu n around the vagina and ribs of a cow. He could not explain how it worked, but it had been advised to him long ago and it definitely worked. He said that his neighbour's ox had had huge intsumpa all over its dewlap. Xolani had advised him to use intambo, but the man also bought a salt solution to rub on the intsumpa. The ox was clean now, but it was not clear which thing did the trick, in this case. Either one or both working together could have worked, he said.

To treat contagious abortion, Nor gave his cows amayeza that he got from a man called Jovose in a nearby village. He did not provide any further information about this medicine and, typical of him and others, seemed to be ur ested in it except for its efficacy. When Non s cattle were sick, he would ask Xolani for help with providing the medicine and injections. He mentioned getting Hi-tet from Xolani. He also gave Xolani money to buy acaricide (Triatix) for him in a nearby town and he used Xolani's knapsack and pump to spray his cattle.

Xolani told me he lost six cattle in 200 . There was plenty of idakada (liverfluke) h the village at that time. Other people were also losing cattle, so it was reassuring not to be the only person to lose so many cattle and he did not suspect anything 'bad' directed at him personally. 
Going to a traditional healer to ascertain the supernatural cause was not an option for Xolani, because 'you don't know which of their many stories to believe: they will tell you about things that have happened and some things that will [read 'might'] happen to you. You are easily confused by such nonsense.' When his six cattle died, Xolani was away on police deployment. He asked his uncle, Nqoyi, to come around to check the cattle and to do post-mortems on the animals. His younger adult brother Zamuxolo was still in the village, so he was relaxed as he knew Zamuxolo would be part of this procedure.

For a difficult birth, Fakati, a man with nearly 100 head of cattle, always tried to assist with the birth himself, rather than call Mr Gobani, the accepted expert in the village for dealing with difficult births. In any case, he claimed that Mr Gobani was ‘an old man now and can't go running all over the village to sort these things out'. Actually, Fakati did not trust anyone other than his four sons to help him with his especially large herd that had caused some disquiet in a village where only half the homesteads had any cattle and average cattle holdings were around five head.

Another herder, Themba, was 38 years old; he was an agricultural science graduate from the University of Fort Hare and had an MSc in Rangeland Science from another highly rated university. He held a senior management position in a government agency in the large regional city of East London. He was a very successful and very keen 'scientific' cattle farmer in the often trying communal environment that is rural Ngqushwa Municipality. By this, I mean that his herd management was underpinned by his academic training sustained empirical observation and scien (1) xperimentation.

This background made Themba quick to dismiss as 'ignorance' much of what constituted the veterinary regimes of the other cattle farmers around him. Interestingly, he was as quick to dismiss scientific 'textbook stuff' as nonsense if it did not square with his experience and local knowledge of village husbandry conditions. While he acknowledged the efficacy of local remedies for some livestock ailments, he had sufficient money to consistently buy veterinary medicines for tick-borne and other serious livestock diseases. Since he felt highly aggrieved when any of his animals succumbed to disease, he maintained a ris Is and thus expensive animal health regir that was driven by a strict timetable from which he hardly deviated. But this was only for the benefit of his own substantial herd of 40 cattle and did not benefit the cattle owned by others in the village.

To maintain this regimen, he car $\sum$ wn to his home in rural Peddie every weekend to oversee, inspect and personally dose his animals. Over recent years, he had tried to impart some of his knowledge to the other stock owners in the village, particularly in respect of tick management, which needs a collective effort if it is to have any lasting impact. He had had very limited success in sharing his formal agricultural knowledge and indeed practical experience with the older men of the village. He reasoned that they resented his runaway success with expanding his herd and were jealous of his successful career. Interviews with the older men in the village suggested that they did not like his independentminded nature, which they took to be highly disrespectful of them and their seniority in terms of age. They would also have valued a financial contribution from him for the purchase of the expensive acaricide treatments that were used in the communal diptank. Despite frequent sanctions against him for not acting in unison with the rest of the livestock owners, Themba had consistently not dipped his cattle with the other villagers at the village diptank, because he regarded this as 'a waste of time' as the facility was poorly managed. Instead, for contr ick-borne diseases he preferred to spray ("dose his cattle himself.

Xolani (mentioned above) was an age-mate of Themba and was employed as a policeman outside the village. Although he had grown up in the village and had his own store of bovine knowledge, he said he had discussions with his trusted friend Themba about how to get the best from his cattle production. From Themba, Xolani learnt that it was good to have a tick-load on the animals so as to build up their natural immunities to tick-borne diseases. He admitted that he did not quite understand how this worked, but Themba convinced him that if you dip and spray all the time, you do not allow the animals to become strong on their own. So even though the sight of ticks on the animals was worrying, Xolani now tried to fight the urge to keep them totally clean. When he sprayed his 
animals in the cattle enclosure, the ticks fell off right there, but no sooner were the animals back in the fields than they were covered with ticks again. This was a stressful situation that called for a strong nerve. Nevertheless, Xolani's herd was growing steadily, not least because he had the wherewithal to purchase veterinary medicines 5 d when required.

section has demonstrated the complex and unevenly distributed hybrid knowledge that exists in relation to bovine diseases and their treatment. Trust and thus certification of knowledge claims emerge as particularly challenging for herders.

\section{The Political Economy and Contestations around 'Local Knowledge'}

So much for the endogenous parameters of people' 1 l knowledge and its gaps. At the level of poli 2 economy, these rural African livestock keepers have long had a generalized mistrust of the 'white' (i.e. European) proponents of veterinary science. This is historically linked to government programmes to control livestock numbers through culling and taxation that used the cattle dipping and inoculation programmes as the government's main sources of contact with African farmers (Bundy, 1987). In fact, their scepticism extends to veterinarians, cattle speculators, veterinary medicine retailers, 'white' farmers selling cattle to them and indeed textbooks and pamphlets on animal health that are aimed at them. What this (is) ust does is help both to underpin a Xhosa/2 ani agropastoral identity and to feed an intentional disregard ('ignorance') for the official 'scientific' view of the causality of bovine diseases. By largely discounting the husbandry and veterinary advice from educated others who are typically regarded as untrustworthy and exploitative, most African cattle farmers in the Eastern Cape constantly replay a script where the critical ingredient in all successful knowledge exchanges, i.e. trust, remains at a nearpermanent low level (Freire, 1970; Sillitoe, 2010).

It might well be asked if it really matters what these livestock farmers know or do about tick-borne animal diseases. In fact, what they know is particularly important in present-day
South Africa, because African herders now hold the country's largest and still steadily increasing proportion of the 'national herds' of livestock, i.e. cattle, goats and sheep (Ainslie, 2002, 2013; Palmer and Ainslie, 2007). In the Eastern Cape Province alone, they are estimated to hold over 3 million head of cattle (ECDA, 2005). Through state land reform and private land purchase, African farmers are slowly acquiring more land on which to run livestock (Beinart and Brown, 2013).

Ticks pose a particular challenge to successful animal husbandry in these ar 0 ot only because they transmit debilitating ine diseases, but also because heavy tick-loads damage the reproductive capacity of cows (by damaging their urinary tracts, udders and teats) and bulls (damaging their genitals) (Masika et al., 1997; Ndhlovu et al., 2009). Animals infected by diseases, whether overtly or sub-clinically, exhibit greater morbidity, are listless and therefore both less productive and less fertile (Tice et al., 1998; Minjauw and McLeod, 2003). Farmers whose ultimate goal is to grow the size of their individual herds know full well that animals in poor health are not fertile and they thus implement practices to counter this situation (Hlatshwayo and Mbati, 2005).

For the reasons recited above, both the knowledge and practices of rural African livestock farmers are characterized by high levels of uncertainty (Ainslie, 2013). In essence, th certainty is around who might be trusted ocal veterinary knowledge and, furthermore, which (expensive) biomedical treatments actually work in the local context at the current conjuncture (see below) to keep animals in reasonable reproductive health.

Somewhat counter-intuitively, it is the case that this uncertainty is more pronounced now under a more benevolent African National Congress government than in the past when the apartheid state intervened more definitively in this sector but also carried most of the financial and institutional burden of animal disease control, including the costly dipping programme to control tick-borne diseases (Beinart, 2007; Brown and Gilfoyle, 2007; Beinart and Brown, 2013). This is because the political transition from apartheid to a democratic order in 1994 was followed by a period of fiscal belt-tightening. In the process, the provincial administrations of the nine new provinces (including the Eastern 
Cape Province) had to bear the financial and institutional costs of the poorly funded provision of veterinary/animal health services. When this system crumbled in the late 1990s, African livestock owners themselves had to step into the breach and take on far greater responsibility, both individually and jointly for dealing with livestock diseases than at any time in the past 100 years (Brown et al., 2013).

What has happened in the past 20 years is that farmers either practise very minimalist tick control or are seemingly indifferent to this aspect of bovine m gement and adopt a 'do-nothing' approach. bur because all their herds of cattle run together on the common rangelands, and are dipped with communally purchased acaricides in common dipping facilities at village level, all farmers 'share' the tick problem and hence the constant burden of tick infestation. To be effective, managing the ticks and the TBDs must be tackled cooperatively, but cattle farmers are individually and collectively uncertain about control strategies and struggle to find adequate and affordable solutions to the challenges that ticks pose.

It is now well known that very limited scientific research was conducted among cattle herds in the reserve/bantustan regions over the decades (Spickett et al., 2007; Beinart and Brown, 2013). This is especially so for the latter half of the 20th century and in relation to animal health. Nevertheless, scientific prescriptions for state intervention in these areas have been required in support of the financial outlay for sustaining the dipping programme. These prescriptions have of course been subject to revisions over time and such revisions have come from essentially two sources: (i) scientific advances and refinements that are driven by the findings of new and innovative veterinary research in the service of the nearby 'white' commercial farming sector; and (ii) the application and modification of scientific advice by farmers in this same sector, in response to a range of exigencies and changes in the nature of their farming enterprises. Scientific prescriptions for the control of TBDs have become increasingly more fluid and complex in the light of, among other things, tick resistance to acaricides and changing tick distributions - in part driven by the increased circulation of wild ungulates as natur erves were established in a number of sites p 2 larly over the past 50 years - and thus of bovine disease patterns in across the countryside (Allsopp, 2009).

Significantly, every revision/advance of scientific knowledge and the related management prescriptions filters imperfectly through to rural African livestock farmers via a variety of formal and informal channels. These include the state veterinary service with its animal health technicians and until the late 1990s, when they were retrenched, the dipping foremen at each village diptank. The channels of information also include the mostly ad hoc interactions African live farmers have with commercial retailers i $\Omega$ terinary products, through their dealings with white farmers from whom they buy heifers and young bullocks, and with cattle buyers and speculators who visit the villages or whom they encounter at the intermittent district livestock sale $\rightarrow$ ch of these channels has specific interests $h$ adhere to it on the part of the provider of information and of the receiver.

The key point is that trust features centrally in the practices of cattle farmers in rural Peddie. Farmers are often reluctant to share knowledge about specific medicines and remedies with each other. A fear of bewitchment by others features in at least some people's animal health routines. This is the realm of more specialist knowledge. When Makhulundaba was asked whether he believes in securing supernatural assistance to keep his cattle healthy, he replied that, since like others here he believes in his ancestors, he tells his ancestors about any new animals that he put in the kraal. The ancestors will look after them for us, because that is what the amaXhosa believe.

Tellingly, diagnosing the cause of an animal's death begins with (frequently vague) descriptions of the animal's behaviour in the lead up to the decision to slaughter it. It continues during the slaughter, with the close examination of various organs, particularly the gall-bladder, spleen, lungs, liver and heart. The most $\mathrm{pr}$ men present must then reach a decision 2 ht what caused the death and whether it is safe to consume the meat or not. In the case of anthrax or bovine tuberculosis they might suggest desisting, but this is not a certain outcome. In any event, the diagnosis when performed so publicly can never involve a full account of the suspected causes of the animal's demise. 


\section{Conclusions}

Relations between cattle farmers and the state (and its various agents) have involved a dynamic but essentially hostile interplay over more than a century, manifest in the tensions and feigned indifference in relation to the trustworthiness and efficacy of scientific and local knowledge. None of these various knowledges in isolation holds the 'answer' to the problem of managing tick-borne diseases. Both 'sides' face serious constraints. Financially constrained African farmers experimenting with all manner of local remedies and thinking through hybrid cultural notions of disease aetiology continue to mistrust state veterinary officials and scientists, who make very occasional, isolated and thus largely unsystematic forays into rural areas to do sporadic surveys into these complex questions.

Given the state's fluctuating but still significant financial outlay on dipping materials, expert veterinary input remains important to plot just where Ngqushwa Municipality and neighbouring areas lie along a gradient of tick resistance to acaricides, in respect of 'endemic stability', the longer-term prevalence/incidence of TBDs and indeed the other major ailments of cattle (cf. Orzech and Nichter, 2008). But it seems this will only be possible after intensive and sustained veterinary research in the area, which, given the present resource constraints, seems unlikely to happen.

Nor would 'improving the science' be a simple undertaking: the seasonal and inter-annual variations in climate (and specifically rainfall) are serious considerations when it comes to understanding any changes in the condition of cattle, which in turn influences their health status and disease susceptibility (Allsopp, 2009). Such variability, coupled with both upswings and downturns in the economic cycle and the on-again, off-again nature of the state's animal health programme, what aspects of animal health are (i) absolutely necessary in an 'objective', practical sense and (ii) affordable for the socio-economically differentiated cattle owners of the villages of Ngqushwa Municipality.

The decline of the state-sponsored dipping programme has meant that for people who do not have much disposable income and who, on the whole, are getting poorer, the privatization of animal health has been ch ging. For the moment, livestock keepers re 2 what they have learned from their fathers and elders, what they can glean from their friends and kinsmen and what they can learn from the suppliers of veterinary medicines.

To conclude, local knowledge about animal health and specifically tick-borne diseases is not shared across the population of rural cattle owners. People have asymmetrical access to this knowledge and the nature of this asymmetry relates directly to the social and politico-economic context in which cattle farmers are located. As Sillitoe has identified in another context, trust emerges as the key ingredient (and in this case, deficit) permeating all the relationships related to the management of animal health. In the absence of trust, the certification of knowledge that is critical to learning, and thus to effective action, remains undeveloped.

\section{Acknowledgements}

Fieldwork was conducted between 2009 and 2012 , as part of a case study contributed in support of an ESRC-funded project, 'Social History of Veterinary Medicine in South Africa since 1930', led by Karen Brown and William Beinart at the University of Oxford. Financial support from this grant and the collegial support of Brown and Beinart are gratefully acknowledged.

\section{References}

Ainslie, A. (2002) Cattle numbers. In: Ainslie, A. (ed.) Cattle Ownership and Production in the Communal Areas of the Eastern Cape, South Africa. Research Report no.10. Programme for Land and Agrarian Studies. University of the Western Cape, Cape Town, pp. 38-45.

Ainslie, A. (2005) Farming cattle, cultivating relationships. Cattle ownership and cultural politics in Peddie District, Eastern Cape. Social Dynamics 31(1), 129-156. 
Ainslie, A. (2013) The socio-cultural contexts and meanings associated with livestock keeping in rural South Africa. African Journal of Range and Forage Science 30(1), 1-4.

Ainslie, A. (2014) Harnessing the ancestors: mutuality, uncertainty and ritual practice in the Eastern Cape Province, South Africa. Africa 84(4), 530-552.

Agrawal, A. (1995) Dismantling the divide between indigenous and scientific knowledge. Development and Change 26, 413-439.

Agrawal, A. (2002) Indigenous knowledge and the politics of classification. International Social Science Journal 54(173), 287-297.

Akerlof, G.A. and Dickens, W.T. (1982) The economic consequences of cognitive dissonance. The American Economic Review 72(3), 307-319.

Allsopp, B.A. (2009) Trends in the control of heartwater. Onderstepoort Journal of Veterinary Research 76, 81-88.

Barth, F. (2002) An anthropology of knowledge. Current Anthropology 43(1), 1-18.

Beck, U. (1999) World Risk Sod Blackwell, Oxford, UK.

Beinart, W. (2007) Transhumand mal diseases and environment in the Cape, South Africa. South African Historical Journal 58(1), 17-41.

Beinart, W. and Brown, K. (2013) African Local Knowledge and Livestock Health. Diseases and Treatments in South Africa. James Currey, Oxford, and W Diversity Press, Johannesburg.

Bennett, J., Ainslie, A. and Davis, J. (2010) Fenced in. $m$ mon property struggles in the management of communal rangelands in Central Eastern Cape Province, South Africa. Land Use Policy 27(2), 340-350.

Bennett, J., Ainslie, A. and Davis, J. (2013) Contested institutions? traditional authorities and land access and control in communal areas of the Eastern Cape Province, South Africa. Land Use Policy 32, 27-38.

Brown, K. and Gilfoyle, D. (2007) Introduction: Livestock diseases and veterinary science in Southern Africa. South African Historical Journal 58(1), 2-16.

Brown, K., Ainslie, A. and Beinart W. (2013) Animal disease and the limits of local knowledge: dealing with ticks and tick-borne diseases in South Africa. Journal of the Royal Anthropological Institute 19(2), 319-337.

Bundy, C. (1987) 'We don't want your rain, we won’t dip': popular opposition, collaboration and social control in the anti-dipping movement 1908-16. In: Beinart, W. and Bundy, C. Hidden Struggles in Rural South Africa. James Currey, London, pp. 191-122.

Cash, D.W., Clark, W.C., Alcock, F., Dickson, N.M., Eckley, N. et al. (2003) Knowledge systems for sustainable development. Proceedings of the National Academy of Sciences 100(14), 8086-8091.

Dilley, R. (2010) Reflections on knowledge practices and the problem of ignorance. Special issue of the Journal of the Royal Anthropological Institute (JRAI), 'Making Knowledge', S176-S192.

Dold, A.P. and Cocks, M.L. (2001) Traditional veterinary medicine in the Alice district of the Eastern Cape Province, South Africa. South African Journal of Science 97, 375-379.

ECDA (2005) ECDA Strategic Plan for 2006. Eastern Cape Department of Agriculture, Bhisho.

Freire, P. (1970) Pedagogy of the Oppressed. Penguin Books, London [1996 revised edition, translated by Myra Bergman Ramos].

Harris, M. (1997) Culture, People, Nature. An Introduction to General Anthropology. Longman, New York.

Hlatshwayo, M. and Mbati, P.A. (2005) A survey of tick control methods used by resource-poor farmers in the Qwa-Qwa area of the Eastern free state province, South Africa. Onderstepoort Journal of Veterinary Research 72, 245-249.

Kirsch, T.G. and Dilley, R. (2015) Regimes of ignorance. An introduction. In: Kirsch, T.G. and Dilley, R. (eds) Regimes of Ignorance. Anthropological Perspectives on the Production and Reproduction of Non-knowledge. Berghahn, New York, pp. 1-28.

Marchand, T.H.J. (ed.) (2010) Making knowledge: explorations of the indissoluble relation between mind, bodies, and environment. Journal of the Royal Anthropological Institute (N.S.) Special Issue, S1-S21.

Masika, P.J., Sonandi, A. and Van Averbeke, W. (1997) Tick control by small-scale farmers in the central Eastern Cape Province, South Africa. Journal of the South African Veterinary Association 68, 45-48.

Minjauw, B. and McLeod, A. (2003) Tick-borne diseases and poverty. The impact of ticks and tick-borne diseases on the livelihood of small-scale and marginal livestock owners in India and Eastern and Southern Africa. Research report, DFID Animal Health Programme, Centre for Tropical Veterinary Medicine, University of Edinburgh, UK.

Modisane, B.M. (2009) Field services: eradication and control of animal diseases. Onderstepoort Journal of Veterinary Research 76, 115-121. 
Moyo, B. and Masika, P.J. (2009) Tick control methods used by resource-limited farmers and the effect of ticks on cattle in the rural areas of the Eastern Cape Province, South Africa. Tropical Animal Health and Production 41, 517-523.

Nasson, B. and Samuel, J. (eds) (1990) Education: From Poverty to Liberty. David Philip, Cape Town.

Ndhlovu, D.N., Makaya, P.V. and Penzhorn B.L. (2009) Tick infestation, and udder and teat damage in selected cattle herds of Matabeleland South, Zimbabwe. Onderstepoort Journal of Veterinary Research 76, 235-248.

Ngqushwa IDP (2002) Ngqushwa Municipality Integrated Development Plan. Unpublished Report. Peddie, Ngqushwa Municipality, Eastern Cape, South Africa.

Orzech, K.M. and Nichter, M. (2008) From resilience to resistance: political ecological lessons from antibiotic and pesticide resistance. Annual Review of Anthropology 37, 267-282.

Palmer, A.R. and Ainslie, A. (2007) Using rain-use efficiency to explore livestock production trends in rangelands in the Transkei, South Africa. African Journal of Range and Forage Science 24(1), 43-49.

Shepherd, C.J. (2010) Mobilizing local knowledge and asserting culture. The cultural politics of in situ conservation of agricultural biodiversity. Current Anthropology 51(5), 629-646.

Sillitoe, P. (1998). The development of indigenous knowledge: a new applied anthropology. Current Anthropology 39(2), 223-252.

Sillitoe, P. (2010) Trust in development: some implications of knowing in indigenous knowledge. Journal of the Royal Anthropological Institute 16(1), 12-30.

Spickett, A.M., Van Der Merwe, D. and Matthee, O. (2007) The effect of orally administered Aloe marlothii leaves on Boophilus decoloratus tick burdens on cattle. Experimental and Applied Acarology 41(1-2), 139-146.

Stone, G.D. (2007) Agricultural deskilling and the spread of genetically modified cotton in Warangal. Current Anthropology 48(1), 67-87.

Tice, G.A., Bryson, N.R., Stewart, C.G., du Plessis, B. and de Waal, D.T. (1998) The absence of clinical disease in cattle in communal grazing areas where farmers are changing from an intensive dipping programme to one of endemic stability to tick-borne diseases. Onderstepoort Journal of Veterinary Research 65, 169-175.

Warren, D.M. (1998) Comments on Sillitoe's 'the development of indigenous knowledge: a new applied anthropology.' Current Anthropology 39(2), 244-245.

Author Query:

[AU 1]: We have shorten the recto running h Please check. 